\title{
Mechanisms of Inhibitory Action of Phenylephrine in Guinea-Pig Taenia Coli
}

\author{
Ryo FUJIHARA, Nobuyoshi SUNAGANE*, Tsutomu URUNO \\ and Kazuhiko KUBOTA \\ Department of Pharmacology. Faculty of Pharmaceutical Sciences. \\ Science University of Tokyo, Shinjuku-ku, Tokyo 162, Japan
}

Accepted February 19, 1986

\begin{abstract}
The effect of phenylephrine, an $\alpha$-agonist, on the $\mathrm{Ca}$ movements and the influence of removal of external $\mathrm{Na}^{+}$on the relaxant activity of phenylephrine were examined in the taenia coli of guinea pigs. Phenylephrine $\left(10^{-7}-10^{-5} \mathrm{M}\right)$ caused dose-dependent relaxation of the taenia coli contracted by $20 \mathrm{mM} \mathrm{KCl}$ in Locke-Ringer solution. Phenylephrine $\left(10^{-5} \mathrm{M}\right)$ suppressed the spike discharges of the taenia coli evoked by $20 \mathrm{mM} \mathrm{KCl}$ without affecting the membrane potential, and this was accompanied by the muscle relaxation. Phenylephrine also inhibited the cellular ${ }^{45} \mathrm{Ca}$-uptake in the taenia coli, but had no discernible effect on the ${ }^{45} \mathrm{Ca}$ efflux from the smooth muscle. These effects of phenylephrine were not observed in a $\mathrm{Na}$-free solution or in the highly depolarized smooth muscle. These findings suggest that the inhibition of $\mathrm{Ca}$-influx in the taenia coli may be involved in the phenylephrine-induced relaxation in the partly depolarized tissue. Reasons for reduction of phenylephrine action encountered under the $\mathrm{Na}$-free condition were also discussed.
\end{abstract}

It is well established that the contractionrelaxation cycle of the smooth muscle is controlled by cytoplasmic $\mathrm{Ca}^{2+}(1)$, and smooth muscle relaxants produce their relaxant action through affecting the $\mathrm{Ca}$ movements of the muscle cells (2-5). It is also well-known that the activation of $\alpha$ adrenoceptor in the intestinal smooth muscle leads to the relaxation of the smooth muscle. However, the relationship between the relaxation and the $\mathrm{Ca}$ movements induced by $\alpha$-adrenoceptor activation remains unclear. Some authors (6-8) suggested that the relaxation of the taenia coli smooth muscle induced by the $\alpha$-adrenergic action of adrenaline is related to the mobilization of intracellularly bound $\mathrm{Ca}$. In contrast, Iwayama et al. (9) observed that phenylephrine augmented $\mathrm{K}$ efflux, but little affected $\mathrm{Ca}$ fluxes and $\mathrm{Ca}$ uptake in the taenia coli.

There are several reports suggesting that $\mathrm{Na}^{+}$plays an important role in regulating the

\footnotetext{
* To whom all correspondence should be addressed.
}

cytoplasmic $\mathrm{Ca}^{2+}$ concentration $(10,11)$ and modifies the activity of smooth muscle relaxants (4, 5, 12, 13). Bülbring and Tomita (14) found that the $\alpha$-adrenoceptormediated relaxing action of adrenaline was reduced when $\mathrm{Na}^{+}$was removed from the bathing fluid, leading them to postulate that the reduction in the adrenaline effect was related to the changes in the $\mathrm{Ca}$ distribution within the smooth muscle cells, which had been caused by the removal of external $\mathrm{Na}^{+}$. However, den Hertog (8) and Watanabe (15) claimed that external $\mathrm{Na}^{+}$is unnecessary for the $\alpha$-adrenaline action. Thus, it is of interest to examine how the relaxant action of $\alpha$ agonists will be influenced when the $\mathrm{Na}^{+}$ gradient across the cell membrane is changed.

In the present study, the authors aimed to explore the mechanisms of the relaxation induced by the activation of $\alpha$-adrenoceptor through examining the effect of phenylephrine on the Ca movements and to elucidate the role of external $\mathrm{Na}^{+}$in the phenylephrineinduced relaxation in the taenia coli. 


\section{Materials and Methods}

Strips of taenia coli were dissected from male guinea pigs weighing 300 to $500 \mathrm{~g}$. The strip was mounted in a $10 \mathrm{ml}$ organ bath filled with Locke-Ringer solution (normal solution) which had the following composition (in $\mathrm{mM}$ ): $\mathrm{NaCl}, 154: \mathrm{KCl}, 5.6$; $\mathrm{CaCl}_{2}, 2.2 ; \mathrm{MgCl}_{2}, 2.1$ : $\mathrm{NaHCO}_{3}, 5.9$ and glucose, $2.8(\mathrm{pH} \mathrm{7.8)}$. The bathing solution was kept at $32^{\circ} \mathrm{C}$ and continuously bubbled with air. The mechanical response of the strip was recorded by an isotonic transducer (ME Commercial Co., Ltd., Tokyo). The smooth muscle preparation was equilibrated for 30 min under loading with $1 \mathrm{~g}$ and then repeatedly treated with hypertonic $20 \mathrm{mM}$ $\mathrm{KCl}$ at intervals of $15 \mathrm{~min}$ until the contractile response of the muscle became constant. In preparing the $\mathrm{Na}$-free or $\mathrm{Na}$-deficient solution, $\mathrm{NaCl}$ in the normal solution was replaced isosmotically by sucrose or equimolarly by Tris- $\mathrm{Cl}$ or choline- $\mathrm{Cl}$, and $\mathrm{NaHCO}_{3}$ was also replaced by $\mathrm{KHCO}_{3}$. In these solutions, the potassium ion concentration was adjusted to approximately the normal level by omitting $\mathrm{KCl}$ from their composition. The $\mathrm{pH}$ of each solution was adjusted to 7.8 by adding $\mathrm{HCl}$. On occasion of the use of choline $-\mathrm{Cl}$ as a $\mathrm{Na}$ substitute, $2 \times 10^{-6} \mathrm{M}$ atropine was added to the solution in order to prevent its cholinergic action.

In order to determine the relaxant activity of phenylephrine in normal. Na-deficient or $\mathrm{Na}$-free solution, phenylephrine was applied cumulatively or in a single dose to the taenia coli precontracted by $20 \mathrm{mM} \mathrm{KCl}$ in each solution. The relaxation induced by phenylephrine was calculated as the percentage decrease of the $\mathrm{KCl}$ contracture.

In order to examine the effects of phenylephrine on the electrical activity of the taenia coli, the membrane potential change and developed tension were measured with the single sucrose-gap method. The organ chamber of the apparatus was continuously circulated with the solution which was kept at $32{ }^{\circ} \mathrm{C}$ and bubbled with $100 \% \mathrm{O}_{2}$. Phenylephrine was infused to the circulating solution. The exchange of the circulating solution in the chamber was carried out so that it was completed within $1 \mathrm{~min}$.
For determining the cellular ${ }^{45} \mathrm{Ca}$-uptake, the taenia coli equilibrated in the normal solution for $30 \mathrm{~min}$ was rinsed for $10 \mathrm{~min}$ in the Ca-free depolarizing solution, which was prepared by adding hypertonic $20 \mathrm{mM}$ or isotonic $50 \mathrm{mM} \mathrm{KCl}$ and by removing $\mathrm{CaCl}_{2}$ to and from the normal or $\mathrm{Na}$-free solution, and then it was immersed for $10 \mathrm{~min}$ in the depolarizing solution containing $1 \mathrm{mM}$ of $\mathrm{CaCl}_{2}$ and ${ }^{45} \mathrm{Ca}(1 \mu \mathrm{Ci} / \mathrm{ml})$ in the presence or absence of phenylephrine. After the tissue was washed with the ice-cold $\mathrm{Ca}$-free solution containing $10 \mathrm{mM} \mathrm{LaCl}_{3}$ for $10 \mathrm{~min}$, it was blotted with ashless filter paper (Whatman No. 42) and quickly weighed.

${ }^{45} \mathrm{Ca}$-efflux was measured according to the method described previously (5). In this experiment, a specially designed apparatus was set up and the recording of the mechanical response and quick collection of the washout solution were simultaneously made. The ${ }^{45} \mathrm{Ca}$-efflux was expressed as the rate constant of ${ }^{45} \mathrm{Ca}$-loss from the muscle.

The radioactivity of the washout solution or in the taenia coli which was digested with a tissue solubilizer, Soluene-350 (Packard Instrument Co.), was counted in a liquid scintillator, Univergel II (Nakarai Chemicals), with a liquid scintillation counter (Aloka, model 651). Drugs and chemicals used were as follows: L-phenylephrine hydrochloride (Sigma), atropine sulfate (Merck), and ${ }^{45} \mathrm{CaCl}_{2}$ (New England Nuclear). The other reagents used herein were of the highest purity available.

\section{Results}

Dose-relaxation curves for phenylephrine in the normal or $\mathrm{Na}$-deficient or $\mathrm{Na}$-free sucrose solution in the smooth muscle precontracted by $20 \mathrm{mM} \mathrm{KCl}$ are shown in Fig. 1. When the muscle bathed in the normal solution was immersed in $\mathrm{Na}$-deficient or $\mathrm{Na}$-free sucrose solution, the muscle tone rose transiently and returned to the initial level during 10-20 min washing with each solution. Thus the muscle was preincubated in the $\mathrm{Na}$-deficient or $\mathrm{Na}$-free sucrose solution for $20 \mathrm{~min}$ or more prior to the application of $\mathrm{KCl}$. Phenylephrine was applied cumulatively to the muscle when 20 $\mathrm{mM} \mathrm{KCl-induced} \mathrm{contracture} \mathrm{reached} \mathrm{a}$ 
plateau level approximately $10 \mathrm{~min}$ after the application of $\mathrm{KCl}$. Phenylephrine $\left(10^{-7}\right.$ $\left.10^{-5} \mathrm{M}\right)$ caused dose-dependent relaxation of the taenia coli depolarized by $20 \mathrm{mM} \mathrm{KCl}$ in the normal solution. The dose-relaxation curve was significantly shifted to the right

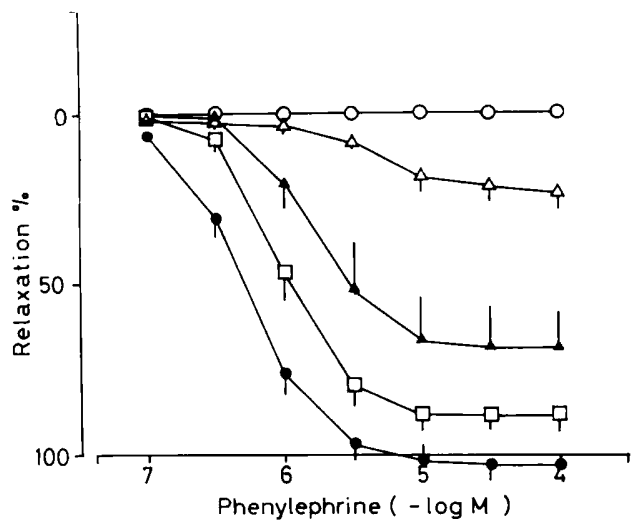

Fig. 1. Influence of changing external $\mathrm{Na}^{+}$concentrations on the relaxing activity of phenylephrine in guinea-pig taenia coli. The dose-relaxation curves for phenylephrine in the $20 \mathrm{mM} \mathrm{KCl}$-depolarized taenia coli were obtained in the normal (O. number of experiments $=24)$. Na-free $(O, n=6), 10 \mathrm{mM}$ $\mathrm{Na}^{+}(\triangle, n=6), 50 \mathrm{mM} \mathrm{Na}^{+}(\boldsymbol{\Delta}, \mathrm{n}=6)$, or $100 \mathrm{mM}$ $\mathrm{Na}^{+}(\square, \mathrm{n}=6)$ solution, in which $\mathrm{NaCl}$ was replaced by sucrose. The relaxation by phenylephrine was calculated as the percentage decrease of the $\mathrm{KCl}$ induced contracture. by an $\alpha$-blocker, phentolamine $\left(3 \times 10^{-6} \mathrm{M}\right)$, but unaffected by a $\beta$-blocker, propranolol $\left(10^{-6} \mathrm{M}\right)$ (data not shown). In the $\mathrm{Na}$-free sucrose solution, phenylephrine failed to cause the relaxation of the taenia coli, while the relaxant activity of phenylephrine was recovered by about $20 \%$ in the presence of $10 \mathrm{mM} \mathrm{Na}^{+}$. Although the extent of recovery of the relaxation was dependent upon the amount of $\mathrm{Na}$ present in the solution, the complete recovery was not obtained even with $100 \mathrm{mM} \mathrm{Na}^{+}$(Fig. 1).

The time courses of the changes in the relaxant activity of phenylephrine in the three different solutions, sucrose-, choline- and Tris-substituted $\mathrm{Na}$-free solutions, were compared since the effects of $\mathrm{Na}$-free solutions on the responsiveness of the taenia coli are variable with the substitutes used for replacing $\mathrm{Na}^{+}$and the length of the periods during which the taenia was exposed to the Na-free solution (16). The changes in the muscle tone after the exposure of the taenia to each $\mathrm{Na}$-free solution were uneven. When the taenia was exposed to each $\mathrm{Na}$ free solution, the muscle tone was initially increased and the increased tone in both the $\mathrm{Na}$-free Tris and choline solution, unlike in the $\mathrm{Na}$-free sucrose solution, did not return to the initial level and persisted at a considerably high level even after washing with them for over $20 \mathrm{~min}$. In order to examine the

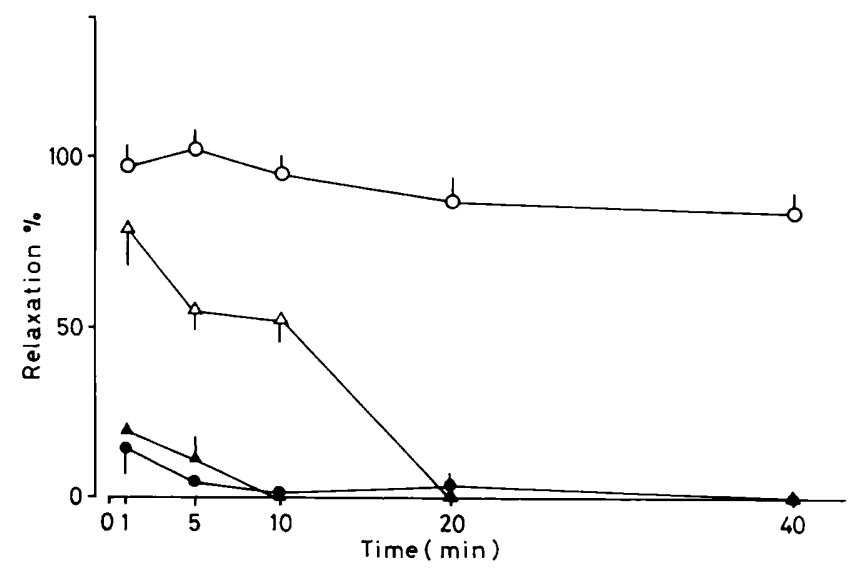

Fig. 2. Effect of phenylephrine $\left(10^{-5} \mathrm{M}\right)$ on the $20 \mathrm{mM} \mathrm{KCl}$ depolarized taenia coli exposed to normal ( $\bigcirc, n=12$ ) and $\mathrm{Na}$-free solutions in which $\mathrm{NaCl}$ was replaced by sucrose (O. $n=4)$, Tris $-\mathrm{Cl}(\triangle, \mathrm{n}=4)$ or choline $-\mathrm{Cl}(\boldsymbol{\Delta}, \mathrm{n}=4)$. The relaxation by phenylephrine was calculated as the percentage decrease of the $\mathrm{KCl}$-induced contracture. 
differences in the phenylephrine action with three $\mathrm{Na}$ substitutes, the taenia was depolarized by $20 \mathrm{mM} \mathrm{KCl}$ at the beginning of the exposure of the muscle to each $\mathrm{Na}$ free solution, the muscle tone was kept in an increased state, and then phenylephrine was applied to the taenia. Figure 2 shows the time course of changes in the relaxant activity of phenylephrine $\left(10^{-5} \mathrm{M}\right) 1,5,10$, 20 or $40 \mathrm{~min}$ after exposure of the taenia to each $\mathrm{Na}$-free solution. Although $10^{-5} \mathrm{M}$ phenylephrine caused a full relaxation of the depolarized taenia coli within $1 \mathrm{~min}$ in the normal solution, its relaxant activity was reduced with the time exposed to each $\mathrm{Na}$ free solution and finally abolished. The reduction in the relaxant activity of phenylephrine was slower in the Tris-substituted solution than in the sucrose- or cholinesubstituted solution.

Figure 3 represents the time-relaxation curves for $10^{-5} \mathrm{M}$ phenylephrine in the solutions containing different concentrations of $\mathrm{Na}^{+}$in which $\mathrm{NaCl}$ was replaced with sucrose, choline or Tris. Phenylephrine was applied to the depolarized taenia $10 \mathrm{~min}$ after the exposure to the sucrose- or cholinesubstituted solution and $20 \mathrm{~min}$ after to the Tris-substituted solution. The relaxant action of phenylephrine was abolished in each $\mathrm{Na}$ free solution. The relaxant effect of phenylephrine was dose-dependently restored by the readmission of $\mathrm{Na}^{+}$into the respective $\mathrm{Na}$-free solution (Fig. $3 \mathrm{a}, \mathrm{b}$ and $\mathrm{c}$ ). In contrast, the effect of Tris on the phenylephrine action was different from those of sucrose or choline. The relaxant activity of phenylephrine was more sensitively restored in the presence of $\mathrm{Na}^{+}$in the Tris-substituted solution (Fig. $3 c)$, as compared with the sucrose- and choline-substituted solutions (Fig. $3 a$ and b).

The effects of phenylephrine on the electrical and mechanical activities in the taenia coli are shown in Fig. 4. In the normal solution, an application of $20 \mathrm{mM} \mathrm{KCl}$ to the taenia caused a depolarization of the membrane with spike discharges and a sustained contraction. When phenylephrine $\left(10^{-5}\right.$ M) was applied to the muscle during the depolarization, the membrane potential was little affected, while the spike discharges were completely suppressed and a full relaxation was observed (Fig. 4a). On the other hand, $20 \mathrm{mM} \mathrm{KCl}$ evoked the contraction and the
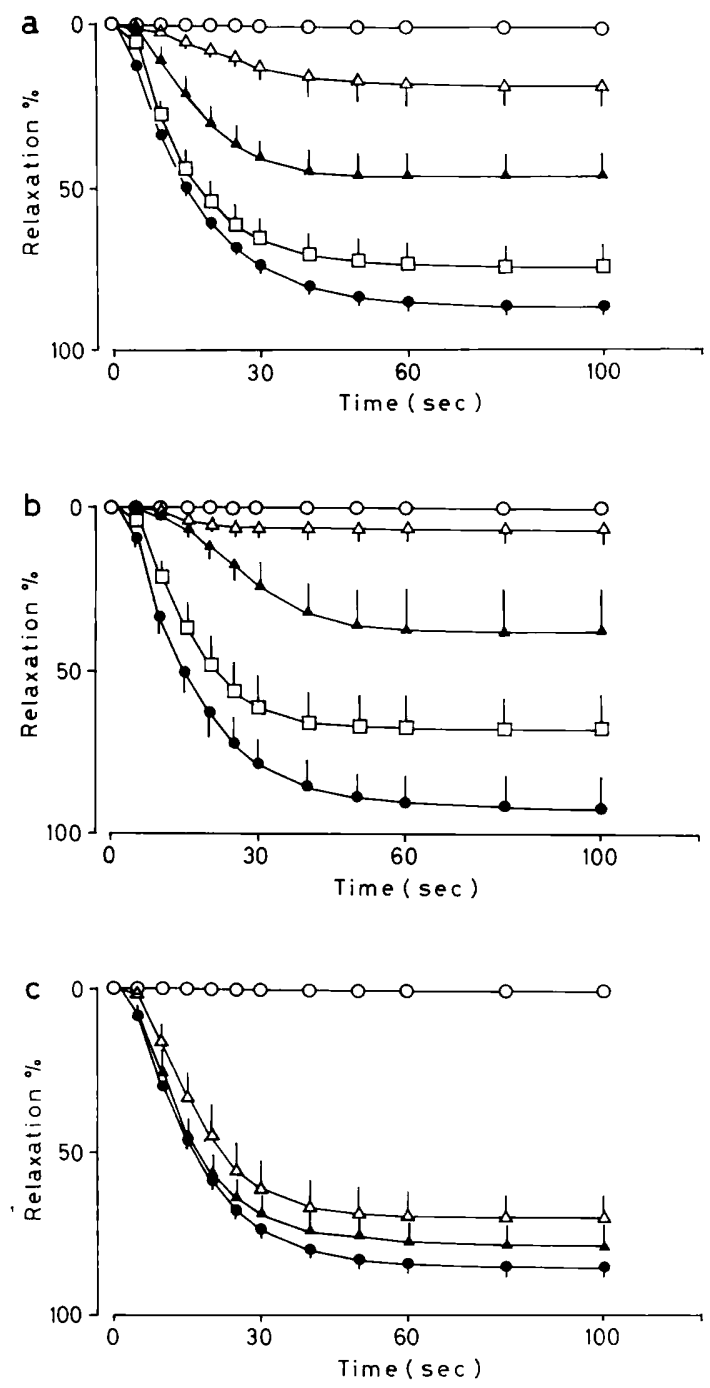

Fig. 3. Effects of sodium ion on the relaxing activity of phenylephrine. Time-relaxation curves for phenylephrine $\left(10^{-5} \mathrm{M}\right)$ in the taenia coli depolarized by $20 \mathrm{mM} \mathrm{KCl}$ were obtained in the normal (O. $\mathrm{n}=16)$. Na-free $(\mathrm{O}, \mathrm{n}=4), 10 \mathrm{mM} \mathrm{Na}^{+}(\Delta, \mathrm{n}=4)$, $50 \mathrm{mM} \mathrm{Na}^{+}(\boldsymbol{\Delta}, \mathrm{n}=4)$, or $100 \mathrm{mM} \mathrm{Na}^{+}(\square, \mathrm{n}=4)$ solution, in which $\mathrm{NaCl}$ was replaced by sucrose (a). choline- $\mathrm{Cl}$ (b) or Tris- $\mathrm{Cl}$ (c). Phenylephrine was applied at $10 \mathrm{~min}$ ( $a, b$ ) and $20 \mathrm{~min}$ (c) after exchanging the normal solution to the respective $\mathrm{Na}$-deficient one noted above. The relaxation by phenylephrine was calculated as the percentage decrease of the $\mathrm{KCl}$-induced contracture. 
a) Normal

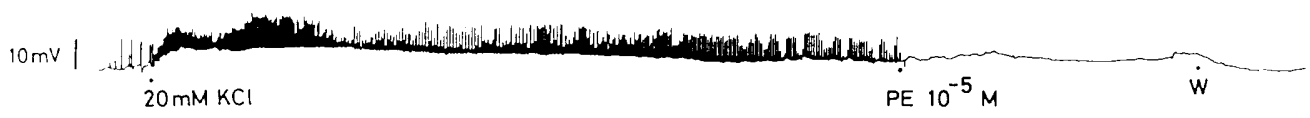

imin

b) Na-free

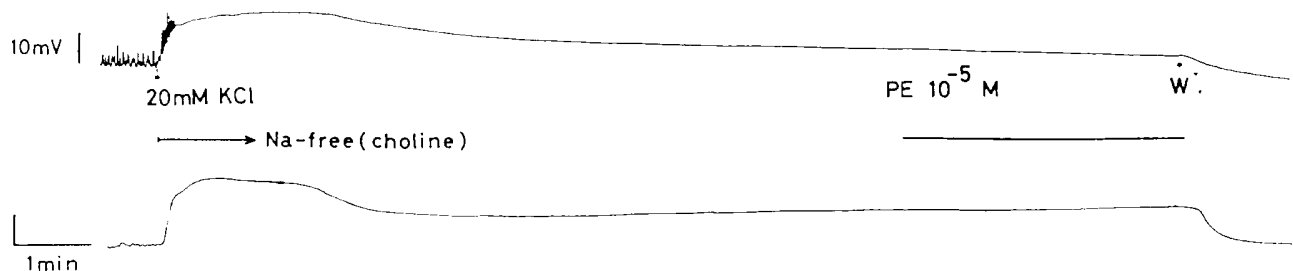

Fig. 4. Effect of phenylephrine $\left(10^{-5} \mathrm{M}\right)$ on the mechanical (lower trace) and electrical (upper trace) activities of the taenia coli depolarized by $20 \mathrm{mM} \mathrm{KCl}$ in normal(a) and $\mathrm{Na}$-free (choline substitution) (b) solutions. Horizontal bars show the duration of phenylephrine application. At $W$, the drug was washed out with the normal solution.

Table 1. Effect of phenylephrine on the cellular ${ }^{45} \mathrm{Ca}$-uptake of depolarized taenia coli in normal or Na-free solution

\begin{tabular}{|c|c|c|c|c|}
\hline & & \multicolumn{3}{|c|}{ Inhibition \% (mean \pm S.E. $)^{\text {a }}$ in } \\
\hline & & $\begin{array}{l}\text { Normal soln. } \\
+20 \mathrm{mM} \mathrm{KCl}\end{array}$ & $\begin{array}{l}\text { Na-free soln. } \\
+20 \mathrm{mM} \mathrm{KCl}\end{array}$ & $\begin{array}{l}\text { Normal soln. } \\
+50 \mathrm{mM} \mathrm{KCl}\end{array}$ \\
\hline \multirow{3}{*}{ Phenylephrine } & $10^{-6} \mathrm{M}$ & $15.1 \pm 5.2^{b}(6)$ & - & $\longrightarrow$ \\
\hline & $10^{-5} \mathrm{M}$ & $16.8 \pm 4.9^{b}(4)$ & $6.4 \pm 8.9(4)$ & $-0.5 \pm 7.4(4)$ \\
\hline & $10^{-4} \mathrm{M}$ & 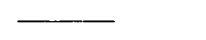 & $-9.2 \pm 3.1(4)$ & $\longrightarrow$ \\
\hline
\end{tabular}

depolarization of the muscle in the $\mathrm{Na}$-free choline solution, but caused no spike discharges. Phenylephrine exerted no appreciable effect on the $20 \mathrm{mM} \mathrm{KCl-evoked}$ changes in the membrane potential and the tension of the muscle (Fig. 4b). The similar results were obtained in the sucrose- or Trissubstituted solution (data not shown).

Since it is generally accepted that the spike generation in the smooth muscle is dependent upon the influx of extracellular
$\mathrm{Ca}^{2+}(17,18)$, the effect of phenylephrine on the cellular ${ }^{45} \mathrm{Ca}$-uptake in the depolarized taenia coli was examined. Phenylephrine $\left(10^{-6} \mathrm{M} \cdot 10^{-5} \mathrm{M}\right)$ significantly inhibited the cellular ${ }^{45} \mathrm{Ca}$-uptake in the muscle depolarized by $20 \mathrm{mM} \mathrm{KCl}$ in the normal solution, but exerted no effect on that in the Na-free sucrose solution (Table 1). Even a higher dose of phenylephrine $\left(10^{-4} \mathrm{M}\right)$ failed to inhibit the cellular ${ }^{45} \mathrm{Ca}$-uptake in the $\mathrm{Na}$-free solution. 


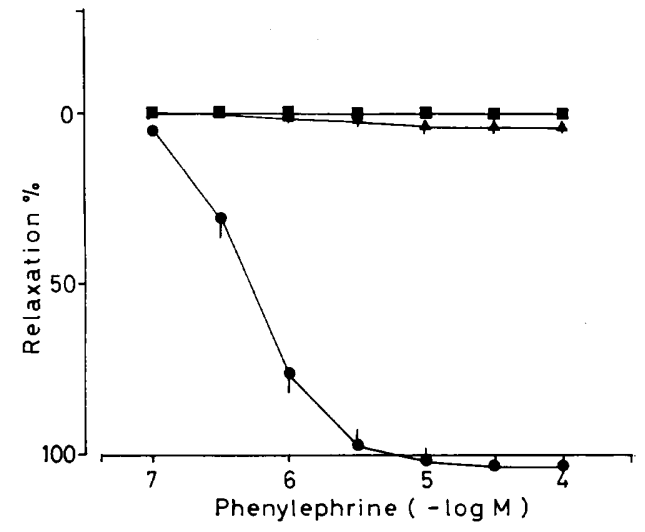

Fig. 5. Effect of phenylephrine on the depolarized taenia coli by hypertonic $20 \mathrm{mM} \mathrm{KCl}$ (O, $\mathrm{n}=12$ ). by hypertonic $40 \mathrm{mM} \mathrm{KCl}(\boldsymbol{\Delta}, n=6)$ and by isotonic $50 \mathrm{mM} \mathrm{KCl}(\boldsymbol{Q}, \mathrm{n}=6)$. Phenylephrine was applied cumulatively to the muscle $10 \mathrm{~min}$ after the application of $\mathrm{KCl}$. The relaxation by phenylephrine was calculated as the percentage decrease of the $\mathrm{KCl}$-induced contracture.

The effects of phenylephrine on the muscle relaxation and the cellular ${ }^{45} \mathrm{Ca}$ uptake in the highly depolarized taenia were also examined. Phenylephrine $\left(10^{-5} \mathrm{M}\right)$ showed no relaxant activity (Fig. 5) and little influenced the cellular ${ }^{45} \mathrm{Ca}$-uptake (Table 1) in the taenia depolarized by isotonic $50 \mathrm{mM} \mathrm{KCl}$ in the normal solution. Furthermore, in the taenia coli depolarized by hypertonic $40 \mathrm{mM} \mathrm{KCl}$, phenylephrine also failed to induce the relaxation of the muscle (Fig. 5), indicating that the disappearance of phenylephrine action in the muscle depolarized by isotonic $50 \mathrm{mM} \mathrm{KCl}$ is not due to osmotic changes.

Figure 6 shows the effects of phenylephrine on the ${ }^{45} \mathrm{Ca}$-efflux from the depolarized taenia coli by $20 \mathrm{mM} \mathrm{KCl}$ and the mechanical response of the taenia coli which was recorded simultaneously with the ${ }^{45} \mathrm{Ca}$ efflux measurement. Phenylephrine $\left(10^{-4} \mathrm{M}\right)$ applied for $20 \mathrm{~min}$ which started $30 \mathrm{~min}$ after the initiation of the ${ }^{45} \mathrm{Ca}$-efflux measurement produced muscle relaxation, but had no effect on the ${ }^{45} \mathrm{Ca}$-efflux.

\section{Discussion}

In the present study, phenylephrine suppressed the spike discharge induced by 20
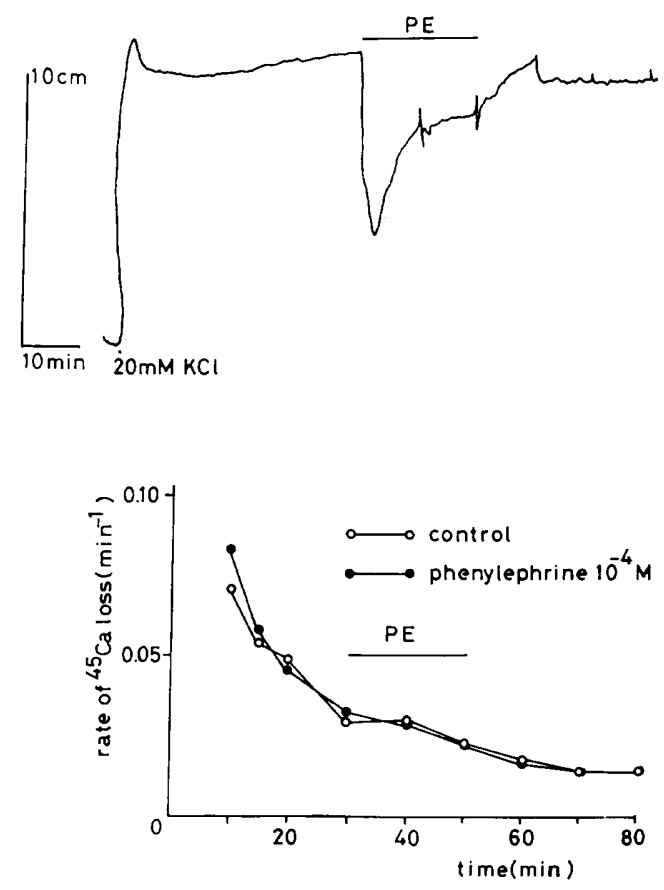

Fig. 6. Effect of phenylephrine on the ${ }^{45} \mathrm{Ca}$-efflux and mechanical activity of the depolarized $(20 \mathrm{mM}$ $\mathrm{KCl}$ ) taenia coli of guinea pigs in normal solution. The upper panel shows the response of the muscle to phenylephrine $\left(10^{-4} \mathrm{M}\right)$. The lower panel shows the effect of phenylephrine $\left(10^{-4} \mathrm{M}\right)$ on the ${ }^{45} \mathrm{Ca}$ efflux. Horizontal bars indicate the duration of phenylephrine application. Data were obtained from 6 experiments, respectively.

$\mathrm{mM} \mathrm{KCl}$ accompanied by a synchronous relaxation of the taenia coli (Fig. 4). Magaribuchi and Kuriyama (12) and Weisbrodt et al. (19) also obtained similar results by using $\alpha$-agonists such as adrenaline and noradrenaline. In addition, we observed that phenylephrine significantly inhibited the cellular ${ }^{45} \mathrm{Ca}$-uptake in the taenia coli partly depolarized by $20 \mathrm{mM} \mathrm{KCl}$. As described previously $(18,19)$ in the results, the spike generation in the smooth muscle of the guinea-pig taenia coli is due to the inward movement of $\mathrm{Ca}^{2+}$. Thus, it is likely that the relaxant action of an $\alpha$-agonist may be primarily due to the inhibition of the inward $\mathrm{Ca}$ movement. On the other hand, phenylephrine exerted no effect on the ${ }^{45} \mathrm{Ca}$-efflux from the partly depolarized taenia coli of guinea pigs, indicating that the $\alpha$-agonist- 
induced relaxation of the smooth muscle is not related to the acceleration of $\mathrm{Ca}$-efflux.

Iwayama et al. (9) have studied the effect of phenylephrine on the cellular calcium movements in the polarized taenia coli, demonstrating that phenylephrine does not inhibit the cellular ${ }^{45} \mathrm{Ca}$-uptake. In addition, they observed that phenylephrine caused the hyperpolarization in the polarized taenia coli smooth muscle. Other $\alpha$-agonists such as adrenaline and noradrenaline were also reported to cause the hyperpolarization in the polarized muscle preparations (7, 8. $14,20,21)$. In the present study, however. phenylephrine produced little effect on the membrane potential of the taenia coli partly depolarized by $20 \mathrm{mM} \mathrm{KCl}$, although it suppressed the spike discharges as shown in Fig. 4. The discrepancy between their results and ours may be mainly attributed to the differences in the experimental conditions. In the depolarized muscles, the Ca-influx should increase, and phenylephrine may act predominantly on the Ca-influx.

Den Hertog (8) reported that $\alpha$-receptormediated action of adrenaline little influenced the cellular ${ }^{45} \mathrm{Ca}$-uptake of the taenia depolarized by isotonic $50 \mathrm{mM} \mathrm{KCl}$. In the present study, phenylephrine also failed to inhibit the cellular ${ }^{45} \mathrm{Ca}$-uptake in the taenia coli depolarized by isotonic $50 \mathrm{mM} \mathrm{KCl}$ (Table 1). Furthermore, the relaxant action of phenylephrine was completely inhibited in the taenia depolarized by isotonic $50 \mathrm{mM}$ or hypertonic $40 \mathrm{mM} \mathrm{KCl}$. These results suggest that in the highly depolarized smooth muscle the inhibitory action of $\alpha$-agonists on the inward movement of calcium might become ineffective and the relaxant activity of $\alpha$ agonists eventually disappear. Meanwhile, it is known that the spike generation is ceased in the highly depolarized muscle, probably because of the depolarization block $(12,19)$. In fact, the spike discharges disappeared in the taenia coli depolarized by isotonic $50 \mathrm{mM}$ or hypertonic $40 \mathrm{mM} \mathrm{KCl}$ (data not shown). Thus, the inhibitory action of $\alpha$-agonists on the inward calcium movement seems to be effective only in such conditions as when the spike discharges are being generated.

It is well documented that the relaxation of the taenia coli of guinea pigs in response to $\alpha$-agonists is related to the acceleration of $\mathrm{K}^{+}$flux $(8,9,22)$, while the role of $\mathrm{Na}^{+}$on the $\alpha$-adrenergic action remains nuclear. The present results demonstrated that the relaxant action of phenylephrine was completely lost in the $\mathrm{Na}$-free solution in which $\mathrm{Na}^{+}$was replaced by substitutes such as sucrose, choline and Tris, but restored in proportion to the amount of $\mathrm{Na}^{+}$readded to the $\mathrm{Na}$-free solution. These findings suggest that the presence of external $\mathrm{Na}^{+}$may be essential for the operation of the relaxation mechanisms mediated via $\alpha$-adrenoceptors. Meanwhile, the fact that the relaxant action of phenylephrine completely disappeared in the Trisand choline-substituted $\mathrm{Na}$-free solutions containing normal $\mathrm{Cl}^{-}$concentration may indicate that the role of chloride ion in the relaxing action of phenylephrine is, if any, minimal. This view is in line with that of Jenkinson and Morton (23).

Since the external $\mathrm{Na}^{+}$is known to be important for the generation of the spike potential (24), the removal of external $\mathrm{Na}^{+}$ should influence the $\mathrm{KCl}$-induced spike discharges. In fact, the spike discharges of the taenia coli could not be generated in the $\mathrm{Na}$-free solution even when the muscle was depolarized by $20 \mathrm{mM} \mathrm{KCl}$. This fact indicates that the smooth muscle contraction in the $\mathrm{Na}$-free solution may be evoked via some mechanisms other than those related to the Ca-spikes. The present study further showed that phenylephrine failed to inhibit the cellular ${ }^{45} \mathrm{Ca}$-uptake in the partly depolarized taenia coli in the $\mathrm{Na}$-free solution. These facts may account for the loss of the relaxant action of phenylephrine in the $\mathrm{Na}$-free solution, that is, the calcium mobilizing pathways associated with muscle contraction may be converted from phenylephrinesensitive ones to phenylephrine-insensitive ones with the removal of the external $\mathrm{Na}^{+}$. Some authors $(25,26)$ postulated that under the external $\mathrm{Na}$-depleted condition, calcium can enter into the vascular smooth muscle cells through the channel which is usually occupied by sodium. If it is the case in the guinea-pig taenia coli, the channel may function as the calcium mobilizing pathway for the contraction induced by $\mathrm{KCl}$ in the $\mathrm{Na}$ free solution. In this context, phenylephrine 
is supposed to be insensitive to the channel.

In conclusion, phenylephrine causes the relaxation of the $20 \mathrm{mM} \mathrm{KCl}$-depolarized taenia coli through inhibiting the inward movement of $\mathrm{Ca}^{2+}$ in the muscle cells in the medium containing a normal concentration of $\mathrm{Na}^{+}$, but loses its relaxant action in the $\mathrm{Na}$ free media probably because it becomes insensitive to the altered Ca-mobilization under $\mathrm{Na}$-free conditions.

\section{References}

1 Ebashi, S. and Endo, M.: Calcium ions and muscle contraction. Prog. Biophys. Mol. Biol. 18, 123-183 (1968)

2 Takayanagi, I., Karasawa, A. and Kasuya, Y.: Relaxation of depolarized guinea pig taenia caecum induced by some antispasmodics. Eur. J. Pharmacol. 50, 137-143 (1978)

3 Sunagane, N., Uruno, T. and Kubota, K.: Mechanism of relaxant action of papaverine. II. Differences between modes of relaxant effects of papaverine and amytal in guinea-pig taenia coli. J. Pharmacobiodyn. 6, 209-216 (1983)

4 Sunagane, N., Sakata, T., Uruno, T. and Kubota, K.: Mechanism of relaxant action of papaverine. III. Comparison of sodium ion dependencies on the relaxant effects of papaverine, aspaminol and benactyzine in guinea-pig taenia coli. J. Pharmacobiodyn. 6, 466-474 (1983)

5 Sunagane, N., Ogawa, T., Uruno, T. and Kubota, K.: Mechanism of relaxant action of papaverine. VI. Sodium ion dependence of its effect of ${ }^{45} \mathrm{Ca}$ efflux in guinea-pig taenia coli. Japan. J. Pharmacol. 38, 133-139 (1985)

6 Bülbring, E. and Kuriyama, H.: The action of catecholamines on guinea-pig taenia coli. Philos. Trans. R. Soc. Lond. [Biol.] 265, 115-121 (1973)

7 Bülbring, E. and Tomita, T.: Calcium requirement for the $\alpha$-action of catecholamines on guineapig taenia coli. Proc. R. Soc. Lond. [Biol.] 197, 271-284 (1977)

8 Den Hertog, A.: Calcium and the $\alpha$-action of catecholamines on guinea-pig taenia caeci. J. Physiol. (Lond.) 316, 109-125 (1981)

9 Iwayama, Y., Takayanagi, I. and Kasuya, Y.: Inhibitory alpha-adrenergic action of phenylephrine in guinea pig taenia caecum. Japan. J. Pharmacol. 29, 349-356 (1979)

10 Aaronson, P. and van Breemen, C.: Effects of sodium gradient manipulation upon cellular calcium, ${ }^{45} \mathrm{Ca}$ fluxes and cellular sodium in the guinea-pig taenia coli. J. Physiol. (Lond.) 319,
443-461 (1981)

11 van Breemen, C., Aaronson, P. and Loutzenhiser, R.: Sodium-calcium interactions in mammalian smooth muscle. Pharmacol. Rev. 30, 167-208 (1979)

12 Magaribuchi, T. and Kuriyama, $\mathrm{H}$.: Effects of noradrenaline and isoprenaline on the electrical and mechanical activities of guinea pig depolarized taenia coli. Japan. J. Physiol. 22, 253270 (1972)

13 Sunagane, N., Fujihara, R., Uruno, T. and Kubota, K.: Mechanism of relaxant action of papaverine. IV. Roles of sodium ion and cyclic AMP. Japan. J. Pharmacol. 35, 461-464 (1984)

14 Bülbring, E. and Tomita, T.: The $\alpha$-action of catecholamines on the guinea-pig taenia coli in $\mathrm{K}$-free and $\mathrm{Na}$-free solution and in the presence of ouabain. Proc. R. Soc. Lond. [Biol.] 197, 255-269 (1977)

15 Watanabe, H.: inhibitory mechanisms of isoprenaline in the guinea-pig taenia coli. Japan. J. Pharmacol. 26, 217-225 (1976)

16 Brading, A.F., Burnett, M. and Sneddon, P.: The effect of sodium removal on the contractile responses of the guinea-pig taenia coli to carbachol. J. Physiol. (Lond.) 306, 411-429 (1980)

17 Bülbring, E. and Tomita, T.: Effect of calcium barium and manganese on the action of adrenaline in the smooth muscle of the guinea-pig taenia coli. Proc. R. Soc. Lond. [Biol.] 172, 121136 (1969)

18 Brading, A., Bülbring, E. and Tomita, T.: The effect of sodium and calcium on the action potential of the smooth muscle of the guinea-pig taenia coli. J. Physiol. (Lond.) 200, 637-654 (1969)

19 Weisbrodt, N.W., Hug, C.C., Jr. and Bass, P.: Separation of the effects of alpha and beta adrenergic receptor stimulation on taenia coli. J. Pharmacol. Exp. Ther. 170, 272-280 (1969)

20 Bülbring, E. and Tomita. T.: Increase of membrane conductance by adrenaline in the smooth muscle of guinea-pig taenia coli. Proc. R. Soc. Lond. [Biol.] 172, 89-102 (1969)

21 Bülbring, E. and Tomita, T.: Suppression of spontaneous spike generation by catecholamines in the smooth muscle of the guinea-pig taenia coli. Proc. R. Soc. Lond. [Biol.] 172, 103-119 (1969)

22 Den Hertog, A., Pielkenrood, J., Pas, R. and van den Akker, J.: The contribution of calcium and potassium to the $\alpha$-action of adrenaline on smooth muscle cells of the portal vein, pulmonary artery and taenia caeci of the guinea-pig. Eur. J. 
Pharmacol. 98, 223-234 (1984)

23 Jenkinson, D.H. and Morton, K.M.: The effect of noradrenaline on the permeability of depolarized intestinal smooth muscle to inorganic ions. J. Physiol. (Lond.) 188, 373-386 (1967)

24 Bülbring, E. and Kuriyama, H.: Effect of changes in the external sodium and calcium concentrations on spontaneous electrical activity in smooth muscle of guinea-pig taenia coli. J. Physiol. (Lond.) 166, 29-58 (1963)
25 Yamamoto, Y. and Hotta, K.: Mechanisms involved in contraction of smooth muscles of the rat portal vein as induced by sodium depletion. Japan. J. Physiol. 35, 717-727 (1985)

26 Itoh, T., Suzuki, H. and Kuriyama, H.: Effects of sodium depletion on contractions evoked in intact and skinned muscles of the guinea-pig mesenteric artery. Japan. J. Physiol. 31, 831847 (1981) 